\title{
Putting together the pieces: building a reaction- centric electronic lab notebook for mobile devices
}

\author{
Alex Clark \\ From 9th German Conference on Chemoinformatics \\ Fulda, Germany. 10-12 November 2013
}

The presentation will describe 4 years of work creating chemical structure based user interfaces for mobile devices, combined with creation of cloud-hosted webservices for supporting functionality.

A number of products have been created along the way, for drawing structures and reactions, managing collections of data, searching databases, creating publication quality graphics, sharing and collaborating, calculating properties, and model building for drug discovery research.

The focus will be on the assembly of these core technologies to create a fully featured electronic lab notebook (ELN) product for capturing chemical reactions.

While a number of web or mobile products already exist for laboratory notetaking, none of them provide the high level chemistry understanding and sophisticated cheminformatics functionality that will be described. The ability to combine all of the necessary capabilities onto a mobile device such as an iPhone or iPad demonstrates that this new generation of computing platforms is ready to play an important role in the realm of cheminformatics.

\section{Publish with ChemistryCentral and every scientist can read your work free of charge \\ "Open access provides opportunities to our colleagues in other parts of the globe, by allowing anyone to view the content free of charge." \\ W. Jeffery Hurst, The Hershey Company. \\ - available free of charge to the entire scientific community \\ - peer reviewed and published immediately upon acceptance \\ - cited in PubMed and archived on PubMed Central \\ - yours - you keep the copyright \\ Submit your manuscript here: \\ http://www.chemistrycentral.com/manuscript/}

